\title{
Penyediaan Barang Milik Negara Berbasis Biaya Kepemilikan Total
}

\author{
Rokhmat Taufiq Hidayat ${ }^{\mathrm{a}, 1, *}$, Resi Ariyasa Qadri ${ }^{\mathrm{b}, 2}$ \\ ${ }^{\mathrm{a}, \mathrm{b}}$ Politeknik Keuangan Negara STAN \\ ${ }^{1}$ rtaufiqhidayat@pknstan.ac.id *; ${ }^{2}$ resi.ariyasa@ pknstan.ac.id \\ * corresponding author
}

ARTICLE INFO

Keywords

Government Goods /

Services Procurement;

Government Capital

Expenditure;

Total Cost Ownership;

State-Owned Assets

\begin{abstract}
The procurement of government fixed assets in the form of buildings, business vehicles, and others has not taken into account the entire costs associated with the purchase of fixed assets. The total cost of ownership scheme offers a concept that takes into account the entire costs associated with the purchase, use, maintenance, and disposal of assets.

This study aims to develop a conceptual model based on the assumption that the total cost of ownership can be used by the government in implementing fixed asset capital spending. Through this research it is hoped that the government can improve the efficiency of procurement of fixed assets through the implementation of the total cost ownership scheme.

The method used in this study is the method of literature study by collecting some of the previous research results related to the theory and practice of total cost ownership. The resulting insights from the previous study were then analyzed using theme analysis for abstraction, thus generating a conceptual model of total ownership cost for the procurement of government fixed assets. The result of this study is a general model proposal for the assessment of total cost of ownership which includes a calculation of the total cost associated with the goods to be purchased by the government at each stage of decision-making, from the search and selection stages to the end of the term.
\end{abstract}

\section{PENDAHULUAN}

Pada tahun 2016, Basuki Tjahaja Purnama pernah mengatakan bahwa: "pada tahun 1960, bus yang digunakan seluruhnya bermerek Mercedes, masa sekarang yang dipakai bermerek 'Ahok'. Itu adalah suatu kemunduran" (Sari, 2019). Akhir-akhir ini, polemik pengadaan bus untuk moda transportasi masal di Jakarta kembali menyedot perhatian publik. Bus Trans Jakarta asal negeri tirai bambu yang sempat dilarang pengoperasiannya di Jakarta karena kasus terbakarnya bus dimaksud di daerah Pancoran pada tahun 2016 yang lalu, sekarang mulai kembali mengaspal di jalanan ibukota (Wijaya, 2019).

Sejatinya, fenomena carut marut tersebut berawal dari proses pemilihan pemenang tender (Hidayat, 2015). Dalam proses tersebut, pemerintah menentukan pemenang berdasarkan aturan main: penyedia yang menawarkan barang yang memenuhi spesifikasi teknis dan harga termurah, maka dialah yang menang (Putra, Atmanto, \& Azizah, 2015). Tidak jarang, masalah pun berlanjut seperti yang Basuki Tjahaja Purnama kemukakan: "saya kan pernah sampaikan pada saat pemerintah provinsi DKI hendak mengadakan bus tahun 2013, saya bersikeras, belilah bus yang kelas dunia, tetapi kan mereka mainkan. Oleh karenanya, produsen yang selalu menang itu berasal dari Tiongkok" (Sari, 2019). Bahkan, mencuatnya kasus korupsi terkait pengadaan kendaraan seringkali disebabkan karena adanya tindak permainan, persis seperti apa yang diungkapkan oleh Basuki Tjahaja Purnama, antara penyedia dan pejabat pembuat komitmen yang bersangkutan pejabat pembuat komitmen dalam penelitian ini selanjutnya disebut: manajer proyek- (Amiruddin, 2012; Kurniawan \& Pujiyono, 2018). 
Permasalahan penentuan pemenang tender yang menitikberatkan pada harga termurah seringkali menimbulkan masalah berupa barang yang diperoleh memiliki biaya pemeliharaan yang cukup tinggi di masa setelah barang tersebut digunakan (Walterbusch, Martens, \& Teuteberg, 2013). Ketika membeli suatu barang, jangan hanya harga beli saja yang dipertimbangkan melainkan seluruh biaya yang dikeluarkan selama masa manfaat ekonomis barang dimaksud harus juga menjadi perhatian utama (Ellram \& Siferd, 1998). Pembeli, dalam hal ini pemerintah, seringkali luput dalam memperhitungkan seluruh biaya yang terjadi selama aset tersebut dimanfaatkan, seperti biaya yang berkaitan dengan penggunaan, pemeliharaan, dan disposisi aset (Hagman, Ritzén, Stier, \& Susilo, 2016). Jika seluruh biaya tersebut dimasukkan ke dalam perhitungan harga beli, tentunya masalah moda transportasi massal yang terbakar di Jakarta pada 2016 lalu dapat dihindari.

Di luar sisi moral hazard dari oknum manajer proyek yang nakal, pemerintah seharusnya dapat memasukkan semua unsur biaya yang berkaitan dengan pembelian moda transportasi massal tersebut. Jika semua unsur biaya tersebut dimasukkan, pemerintah akan memiliki justifikasi yang lebih kuat untuk tidak memilih moda transportasi yang berasal dari negeri tirai bambu yang belum teruji dan disangsikan keawetannya. Mekanisme pembelian dengan mempertimbangkan semua faktor biaya yang berkaitan dengan transaksi pembelian tersebut dinamakan total cost ownership (Ellram, 1995; Ferrin \& Plank, 2002).

Beberapa penelitian terdahulu menjelaskan bahwa Konsep total cost ownership merupakan pengembangan dari konsep activity based costing (Ellram \& Siferd, 1998; Johnson \& Kaplan, 1987; Perona, Saccani, \& Bacchetti, 2017). Model total cost ownership sudah mempertimbangkan biaya pembelian dan operasional serta menghitung aspek kualitas dan biaya pemeliharaan (Prabhakar \& Sandborn, 2012). Bahkan, beberapa model total cost ownership sudah memasukkan biaya depresiasi dan nilai jual kembali dalam menghitung total nilai akuisisi aset tetap terkait dengan pembelian kendaraan operasional Pemerintah Amerika Serikat (Spitzley, Grande, Keoleian, \& Kim, 2005).

Sustainabilitas lingkungan menjadi pertimbangan penting dalam model total cost ownership yang digunakan berbagai industri di Inggris (Baines et al., 2007). Biaya awal untuk keputusan strategis, pemilihan layanan cloud-computing dan tipe cloud menjadi komponen utama dalam model total cost ownership yang diimplementasikan oleh industri teknologi informasi di Jerman (Walterbusch et al., 2013). Namun, model total cost ownership yang dikembangkan dalam beberapa penelitian terdahulu tersebut hanya menitikberatkan pada komponen biaya pembelian dan operasional saja. Seharusnya, pendekatan total cost ownership lebih menitikberatkan pada perspektif pelanggan sehingga lebih memperhatikan secara komprehensif mengenai evaluasi biaya yang dikeluarkan oleh pelanggan, seperti biaya awal pencarian, biaya evaluasi produk-pemasok, serta biaya penghapusan produk pada akhir masa manfaatnya.

Tinjauan menyeluruh dari biaya yang dikeluarkan oleh pelanggan, dari pencarian produk hingga penghapusan, sangat jarang diungkap dalam penelitian-penelitian terdahulu. Secara khusus, biaya pencarian dan pemilihan produk seringkali diabaikan dalam komponen model total cost ownership, sehingga menghasilkan perspektif yang tidak lengkap. Disinilah letak kesenjangan dari beberapa riset terdahulu tersebut. Oleh karena itu, penelitian ini bertujuan untuk memasuki beberapa area yang belum banyak disentuh oleh riset terdahulu tersebut dengan menjawab pertanyaan penelitian: "bagaimana seharusnya model total cost ownership bagi pemerintah selaku pelanggan/konsumen akhir?" Penelitian ini berfokus pada perumusan model total cost ownership dengan mengabstraksi hasil studi literatur terdahulu yang memaparkan berbagai macam model total cost ownership sehingga menjadi informasi bagi konsumen akhir ketika hendak melakukan pembelian barang. Secara umum pendekatan total cost ownership digunakan untuk konteks bisnis-kepada-bisnis. Dalam penelitian ini, perspektif yang digunakan adalah bisnis-kepada-konsumen dalam rangka mengatasi kesenjangan penelitian terdahulu.

\section{METODE}

Metode yang digunakan dalam penelitian ini adalah studi literatur. Kerangka konseptual studi literatur yang diimplementasikan adalah adaptasi dari metode studi literatur Qadri (2019), Khan, Kunz, dan Kleijnen (2003), serta Tranfield, Denyer, dan Smart (2003). Secara umum, tahapan yang dilakukan adalah: 
Gambar 1. Tahapan Studi Literatur (Qadri, 2019)

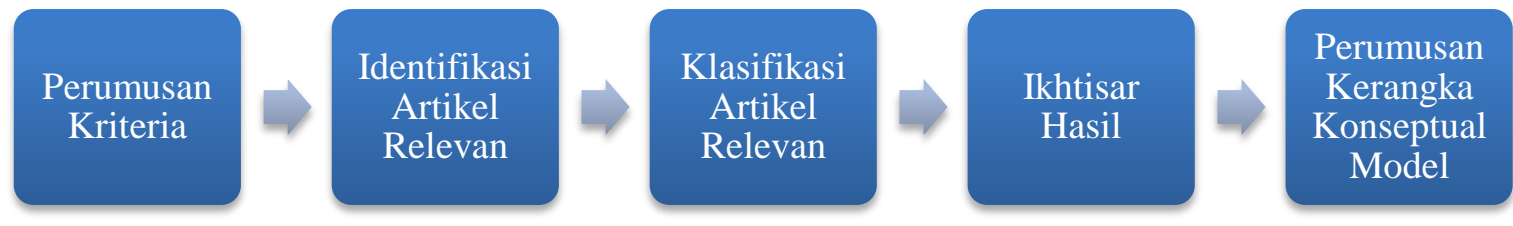

Pada tahap awal, peneliti berhasil mengidentifikasi sebanyak 198 artikel yang berasal dari basis data Scopus dengan menggunakan kata kunci: total cost ownership. Selanjutnya, peneliti melakukan reduksi artikel dengan memasukkan kriteria berupa artikel tersebut harus merupakan seminal paper agar model kerangka konseptual yang dirumuskan dapat sejalan dengan filosofi yang dikembangkan oleh peneliti yang paling berpengaruh dalam pengembangan teori total cost ownership. Diperoleh beberapa artikel yang memenuhi kualifikasi tersebut, yaitu: Ellram (1993c), Ellram (1995), serta Ellram dan Silferd (1998). Setelah itu, perumusan model konseptual dilakukan berdasarkan ketiga seminal papers tersebut.

\section{HASIL DAN PEMBAHASAN}

Total biaya kepemilikan dapat didefinisikan sebagai "jumlah biaya yang berkaitan dengan perolehan, penggunaan, dan penghapusan suatu aset atau lini servis” (Ellram, 1995). Pada dasarnya, konsep total biaya kepemilikan berkaitan dengan life cycle costing, yaitu "suatu teknik analisis biaya yang mencakup keseluruhan biaya terkait suatu produk, mulai dari proses produksi s.d. proses penghapusan" (Sherif \& Kolarik, 1981). Namun, life cycle costing berbeda dari TCO dari sisi life cycle costing mengadopsi perspektif produk dan biaya komputasi terlepas dari siapa subjek yang mengeluarkannya. Sementara TCO mengadopsi sudut pandang pembeli, seperti penghitungan biaya yang terkait dengan pencarian, akuisisi, instalasi, operasional, dan penghapusan barang oleh pelanggan. Dengan demikian, TCO memiliki horizon waktu yang lebih pendek daripada life cycle costing. Penelitian ini mengintisarikan beberapa penelitian terdahulu yang mengembangkan model TCO baru untuk pembelian barang-barang konsumsi yang memiliki umur ekonomis lebih dari setahun, seperti: mobil, mesin percetakan, dan komputer. Model TCO tersebut akan mendukung keputusan pembelian konsumen akhir yang dalam hal ini adalah pemerintah. Sejatinya, model tersebut cocok untuk diterapkan terhadap beberapa kategori belanja modal pemerintah.

Pada dasarnya, model TCO banyak mengadopsi filosofi dari penghitungan biaya berbasis aktivitas yang menghasilkan item biaya. Oleh karena itu, model TCO yang diusulkan dalam penelitian ini mempertimbangkan seluruh unsur biaya mulai dari fase pembelian barang yang termasuk kategori belanja modal sampai dengan fase akhir masa pakai barang dimaksud. Meskipun tujuan utamanya adalah untuk mendukung keputusan belanja modal pemerintah, model TCO yang dikembangkan akan fleksibel untuk melayani tujuan yang berbeda. Gambar 2 menyajikan tentang model TCO yang dikembangkan untuk belanja modal pemerintah berdasarkan beberapa penelitian seminal terkait TCO, yaitu: Ellram (1993b), Ellram (1995), Ellram dan Siferd (1998), serta Ferin dan Plank (2002). Fokus utama adalah aktivitas pemerintah yang terjadi selama siklus hidup barang milik negara dan item biaya yang dihasilkan oleh aktivitas tersebut. Kegiatan tersebut dan biaya terkait dibingkai sesuai dengan proses yang berkaitan dan fase waktu di mana mereka terjadi. 
Gambar 2. Model Konseptual TCO

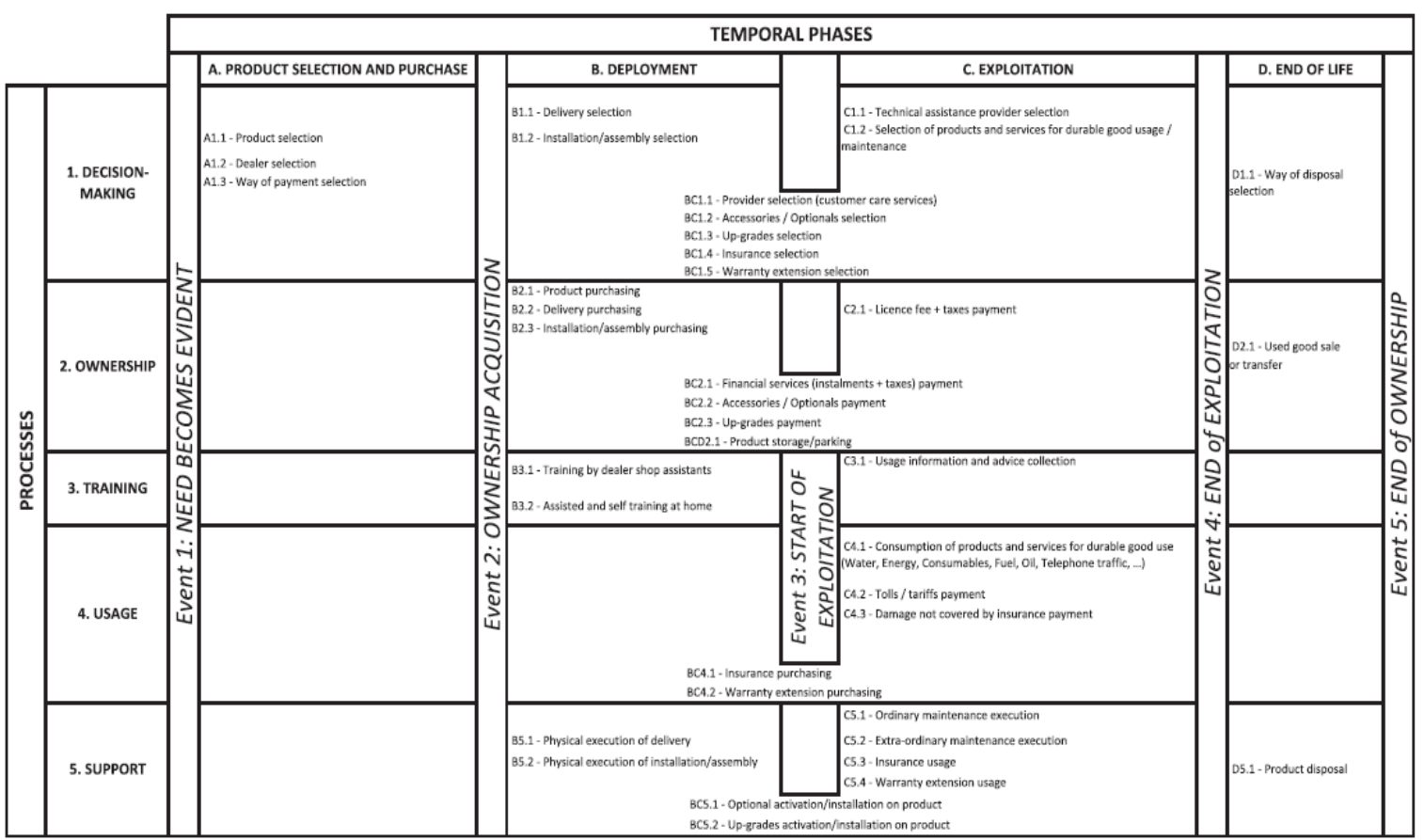

Gambar 2 menggambarkan model aktivitas yang diklasifikasikan berdasarkan fase dan proses. Fase waktu dibagi menjadi empat fase, yaitu: (1) fase pemilihan dan pembelian barang milik negara, mencakup fase pencarian dan akuisisi. Selama fase ini, pemerintah membuat beberapa keputusan: apakah benar-benar membeli barang tersebut, terutama ketika opsi alternatif tersedia, atau tidak; merek dan model apa yang akan dibeli; di mana membelinya; dan bagaimana cara membayarnya. (2) Fase penempatan, meliputi kegiatan yang memungkinkan agar barang dapat digunakan sebagaimana tujuan pengadaannya dan dikuasai oleh pemerintah selaku konsumen akhir. Biaya pada fase ini berkaitan dengan: pengiriman, pemasangan, dan pelatihan. Fase ini berakhir ketika barang siap untuk digunakan. (3) Fase eksploitasi, meliputi fase di mana barang tersebut sudah dicatat sebagai barang milik negara dan dapat digunakan sesuai fungsinya. (4) Fase penghapusan, dimulai ketika pemerintah memutuskan untuk menghapus barang milik negara tersebut dan selesai ketika pemerintah benar-benar memberikannya kepada pihak lain atau memusnahkannya.

Selain itu, model pada Gambar 2 mengidentifikasi lima proses, yaitu: (1) proses pengambilan keputusan yang mencakup kegiatan yang berkaitan dengan pengadaan barang terkait, seperti: perpanjangan garansi dan penambahan aksesori. Aktivitas yang dilakukan pada tahap ini termasuk menentukan persyaratan, mengumpulkan informasi, dan membandingkan berbagai penawaran dari penyedia. (2) Pengelompokkan aktivitas, berkaitan dengan akuisisi dan kepemilikan produk, terlepas dari bagaimana produk tersebut digunakan. (3) Pelatihan, meliputi kegiatan yang dilakukan oleh pemerintah untuk meningkatkan keterampilan para pengguna barang untuk menggunakan dan memelihara barang milik negara. Kegiatan yang dilakukan pada tahap ini termasuk kegiatan memperoleh informasi dan saran melalui dokumentasi teknis atau sumber lain. (4) Penggunaan, mencakup aktivitas yang terkait dengan eksploitasi produk dan konsumsi sumber daya terkait, seperti energi, bahan bakar, air, dan pelumas. (5) Dukungan produk, proses mengelompokkan kegiatan yang mendukung penyebaran, eksploitasi, dan akhir masa pakai produk, seperti pemasangan, pemeliharaan, dan pembuangan. Kegiatan pada Gambar 2 dikodifikasi berdasarkan fase temporer di mana fase tersebut terjadi serta kategori proses yang dimiliki.

\section{Model Biaya}

Item biaya moneter, biaya peluang, dan biaya non-moneter dapat dikaitkan dengan setiap aktivitas yang konsisten dengan pendekatan berbasis nilai. Biaya moneter memperhitungkan seluruh pengeluaran aktual pemerintah yang menghasilkan arus kas negatif, misalnya, jika ada mobil dinas milik pejabat eselon I rusak berat dan harus diperbaiki di bengkel, maka pemerintah yang dalam hal 
ini diwakili oleh Pejabat Pembuat Komitmen akan menanggung biaya untuk perbaikan besar. Biaya moneter dapat diidentifikasi dengan mudah karena nilai tunainya dapat diketahui dengan pasti. Sebaliknya, biaya peluang merupakan biaya yang mengacu pada hilangnya pendapatan yang berkonsekuensi mencegah arus kas positif, misalnya, kerusakan mobil ditambah lagi tidak tersedianya suku cadang mobil tersebut, dapat mencegah pengguna barang untuk melakukan aktivitas berbayar, seperti melakukan rapat di instansi lain. Biaya peluang bersifat eksplisit karena nilai tunainya jelas, sekaligus bersifat subyektif karena bergantung pada pengguna lainnya yang terlibat, dan hubungan mereka dengan aktivitas dapat muncul dalam keadaan tertentu. Biaya nonmoneter, berkaitan dengan upaya yang dilakukan oleh pemerintah selaku pengguna barang untuk aktivitas tertentu. Contoh dari biaya ini adalah apabila terdapat kerusakan pada mobil dinas pejabat eselon II, pengguna barang akan menghabiskan beberapa jam untuk mengangkut mobil ke bengkel dan menunggu saat mobil tersebut diperbaiki. Jika tidak ada arus kas negatif aktual atau biaya peluang, biaya non-moneter dapat dihitung sesuai dengan nilai pada saat itu berdasarkan perspektif pemerintah selaku konsumen akhir. Biaya non-moneter bersifat implisit karena nilai tunainya tidak dapat diketahui dengan jelas dan bersifat subyektif karena nilainya tergantung pada pengguna tertentu yang terlibat.

\section{Model Aplikasi}

Model yang diilustrasikan pada Gambar 2 menggabungkan beberapa elemen berbasis pengguna barang selaku konsumen akhir dan beberapa elemen berbasis produk atau barang. One-on-one TCO evaluation memungkinkan pengguna lainnya untuk menilai TCO berdasarkan model produk tertentu sesuai dengan fitur teknis produk, dan kebiasaan penggunaan pelanggan. Jika evaluasi dilakukan sebelum pembelian, model ini memberikan nilai TCO yang diharapkan dan memungkinkan pemerintah selaku pengguna barang untuk membandingkan TCO yang diharapkan dari model produk yang berbeda, dengan menerapkan model TCO yang sama beberapa kali. Average customer TCO, model aplikasi kedua, menilai TCO rata-rata dari sekelompok model produk untuk pengguna tertentu, misalnya rata-rata TCO model mobil dinas pejabat eselon I di pasaran sesuai dengan kebiasaan penggunaan pejabat yang bersangkutan. TCO rata-rata diperoleh dengan menerapkan model 1 ke berbagai produk milik kelompok yang dipertimbangkan. Model ini memungkinkan penghitungan nilai TCO rata-rata dari kategori produk yang dipertimbangkan untuk pengguna tertentu. Hal ini dapat menyebabkan keputusan untuk membeli mobil dinas baru atau tidak, misalnya, ketika mempertimbangkan apakah pemerintah harus membeli mobil kedua bagi Menteri atau tidak. Average product TCO tidak merujuk kepada pengguna tertentu, tetapi kepada pengguna rata-rata, misalnya, rata-rata populasi atau grup, seperti rata-rata pejabat eselon III di suatu unit lebih suka mobil tipe A atau tipe B.

Model aplikasi ini menilai TCO dari model produk tertentu untuk pengguna "rata-rata" yang termasuk dalam kelompok referensi. Dengan demikian, evaluasi berguna dari sudut pandang produsen untuk menilai total biaya yang dihasilkan oleh model produk tertentu dan membandingkannya dengan model lain, lalu menganalisis dan membandingkan struktur biaya, atau menyediakan pengguna dengan model TCO yang diharapkan dari suatu produk dalam kondisi standar sebelum membeli. Aplikasi keempat dan paling komprehensif adalah average TCO, dihitung dari nilai rata-rata, baik karakteristik populasi pengguna maupun dari serangkaian model produk. Dengan menggunakan model ini, dimungkinkan untuk menghitung TCO rata-rata dari satu set barang milik negara berdasarkan kebiasaan penggunaan rata-rata dari sekelompok pengguna. Dampaknya, output dari aplikasi ini memiliki nilai deskriptif sehingga dimungkinkan untuk menganalisis dampak dari berbagai proses, kegiatan, dan item biaya. Dampak lainnya adalah biaya moneter tidak tergantung pada pengguna barang tertentu atau periode tertentu sehingga biaya tersebut dapat dinilai secara lebih obyektif.

\section{Aplikasi Empiris}

Tantangan dan hambatan untuk implementasi TCO dikelompokkan ke dalam berbagai kategori, seperti kompleksitas, relevansi, budaya organisasi, pendidikan/pelatihan, dan sumber daya (Ellram, 1993a, 1993b; Ellram \& Siferd, 1998). Kategori-kategori tersebut menghambat suatu posibilitas untuk beralih dari implementasi satu model TCO ke penggunaan berkelanjutan (Hagman et al., 
2016; Prabhakar \& Sandborn, 2012). Kompleksitas adalah masalah yang sangat penting ketika menerjemahkan pendekatan TCO ke domain pengguna tertentu. Perhitungan TCO membutuhkan upaya pengumpulan data yang penting yang pada gilirannya akan menghambat implementasi aktualnya oleh pemerintah. Secara umum, beberapa hambatan tersebut didefinisikan sebagai berikut: pertama, tidak semua kegiatan dan item biaya memiliki dampak yang relevan pada TCO; hal ini menunjukkan bahwa model TCO dapat disederhanakan tanpa mempengaruhi nilainya untuk pengambilan keputusan. Kedua, kebutuhan untuk memasukkan biaya peluang dan biaya nonmoneter tergantung pada model aplikasi yang dipilih.

Model aplikasi 1. One-on-one TCO Evaluation dan model aplikasi 2. Average product TCO memungkinkan perhitungan biaya peluang dan non-moneter. Namun di sisi lain, kedua model aplikasi tersebut tidak memerlukan upaya pengumpulan data untuk satu set pengguna barang. Sebaliknya, model aplikasi 3. Average customer TCO dan model aplikasi 4. Average TCO memerlukan upaya signifikan dalam menentukan kebiasaan rata-rata pengguna barang sehingga aplikasi kedua model tersebut tidak memerlukan evaluasi biaya peluang dan biaya non-moneter. Ketiga, peneliti mengakui bahwa adopsi luas dari model TCO ini oleh pemerintah akan membutuhkan ketersediaan sarana dan prasarana untuk mendukung perhitungan, seperti: peralatan teknologi Informasi dan komunikasi yang canggih. Untuk meningkatkan kegunaan praktis model, dapat ditempuh dua langkah utama, yaitu (1) mengurangi kompleksitas model dan (2) mengembangkan peralatan teknologi informasi dan komunikasi yang mumpuni untuk mendukung perhitungan TCO sehingga hal itu akan meringankan upaya pengumpulan data dan mengurangi efek kompleksitas.

Dengan demikian, prosedur yang dapat pemerintah lakukan untuk mengurangi kompleksitas model adalah pertama, penentuan model aplikasi yang ingin diadopsi dan identifikasi kebutuhan data. Kedua, pengujian aplikasi percontohan harus dilakukan untuk menilai relevansi item biaya yang berbeda. Sebagai alternatif, pemerintah dapat menggunakan sumber sekunder yang memberikan perkiraan nilai item biaya berbeda dalam model. Ketiga, simplifikasi model, semua kegiatan dan item biaya terkait yang dianggap tidak relevan dapat dikeluarkan. Keempat, proses implementasi akhir. Dalam hal ini, peralatan teknologi informasi dan komunikasi berbasis web akan mengurangi penggunaan upaya dan meningkatkan adopsi model dalam skala besar oleh berbagai instansi pemerintah. Elemen utama yang dibutuhkan antara lain: (a) server untuk komputasi model TCO, digunakan untuk menggabungkan formulasi item biaya dan prosedur perhitungan; (b) basis data yang berisi daftar model produk terkini di pasar, bersama dengan fitur teknis yang relevan; (c) set parameter yang relevan untuk menghitung biaya; (d) kemungkinan bagi instansi pemerintah untuk memilih produk dan mengisi informasi mengenai kebiasaan penggunaan yang menentukan validitas model TCO. Dengan mengombinasikan prosedur reduksi model dan pengembangan peralatan teknologi informasi dan komunikasi, dimungkinkan bagi pemerintah untuk mendorong adopsi skala besar dari model TCO yang peneliti usulkan.

\section{SIMPULAN DAN IMPLIKASI}

Pendekatan biaya kepemilikan total telah diimplementasikan secara luas pada sektor privat di beberapa negara maju, seperti Amerika Serikat dan Inggris. Namun aplikasi biaya kepemilikan total pada sektor publik, terutama pemerintah masih sedikit mendapat perhatian dari para akademisi dan praktisi di dunia internasional. Penelitian ini bertujuan untuk mengisi kesenjangan tersebut. Secara khusus, penelitian ini mengadopsi perspektif konsumen akhir selaku pembeli dalam mengembangkan model umum untuk penilaian biaya total kepemilikan atas pembelian barang via skema belanja modal pemerintah.

Model yang diusulkan mencakup perhitungan seluruh biaya terkait barang yang akan dibeli oleh pemerintah pada setiap tahap pengambilan keputusan, mulai dari tahap pencarian dan pemilihan barang sampai akhir masa manfaatnya. Ada 4 macam model aplikasi yang menjadi fondasi model biaya kepemilikan total yang diusulkan, yaitu pertama, one-on-one TCO evaluation, digunakan untuk menilai biaya produk tertentu yang berkaitan dengan kebiasaan penggunaannya. Kedua, average product $T C O$, digunakan untuk menilai biaya rata-rata kepemilikan dan penggunaan barang atau untuk membandingkan dua atau lebih kelompok produk yang berbeda. Ketiga, average 
customer TCO, digunakan untuk penghitungan biaya produk tertentu bagi kelompok pengguna tertentu. Keempat, average TCO, digunakan untuk menganalisis model produk rata-rata dan ratarata pengguna.

Berdasarkan model aplikasi yang dipilih, model biaya kepemilikan total yang diusulkan akan: (1) mendukung keputusan pembelian oleh pemerintah, khususnya entitas pengadaan barang/jasa pemerintah; (2) menyuplai hasil perhitungan yang lebih komprehensif untuk menganalisis dampak dari variabel dan parameter yang berbeda pada setiap model biaya total kepemilikan; serta (3) memungkinkan penyedia barang untuk membandingkan penawaran mereka dengan penawaran penyedia lainnya.

\section{DAFTAR REFERENSI}

[1]. Amiruddin. (2012). Pemberantasan Korupsi Dalam Pengadaan Barang/Jasa Pemerintah Melalui Instrumen Hukum Pidana dan Administrasi. Jurnal Media Hukum, 19(1), 125-137.

[2]. Baines, T. S., Lightfoot, H. W., Evans, S., Neely, A., Greenough, R., Peppard, J., ... Wilson, H. (2007). State-of-the-art in product-service systems. Proceedings of the Institution of Mechanical Engineers, Part B: Journal of Engineering Manufacture, 221(10), 1543-1552. https://doi.org/10.1243/09544054JEM858

[3]. Ellram, L. M. (1993a). A Framework for Total Cost of Ownership. The International Journal of Logistics Management. https://doi.org/10.1108/09574099310804984

[4]. Ellram, L. M. (1993b). Total Cost of Ownership : Elements and Implementation. International Journal of Purchasing and Materials Management, Fall, 1-10.

[5]. Ellram, L. M. (1993c). Total Cost of Ownership: Elements and Implementation. International Journal of Purchasing and Materials Management. https://doi.org/10.1111/j.1745-493X.1993.tb00013.x

[6]. Ellram, L. M. (1995). Total cost of ownership; An analysis approach for purchasing. International Journal of Physical Distribution \& Logistics Management. https://doi.org/10.1108/09600039510099928

[7]. Ellram, L. M., \& Siferd, S. P. (1998). Total Cost of Ownership: A Key Concept in Strategic Cost Management Decisions. Journal of Business Logistics, 19(1), 55-84. Diambil dari http://content.epnet.com/ContentServer.asp?T=P \&P=AN\&K=1403161\&EbscoContent=dGJyMMvl7ES ep7Q4y9fwOLCmrlGep65Srqi4Sa6WxWXS\&ContentCustomer=dGJyMPGrsUizqbZMuePfgeyx+Eu3 q64A\&D=buh

[8]. Ferrin, B. G., \& Plank, R. E. (2002). Total Cost of Ownership Models: An Exploratory Study. The Journal of Supply Chain Management, 38(3), 18-29. https://doi.org/10.1111/j.1745493X.2002.tb00132.X

[9]. Hagman, J., Ritzén, S., Stier, J. J., \& Susilo, Y. (2016). Total cost of ownership and its potential implications for battery electric vehicle diffusion. Research in Transportation Business and Management. https://doi.org/10.1016/j.rtbm.2016.01.003

[10]. Hidayat, R. (2015). Penerapan E-Procurement Dalam Proses Pengadaan Barang Dan Jasa Pemerintah Guna Mendukung Ketahanan Tata Pemerintahan Daerah (Studi pada Unit Layanan Pengadaan Barang dan Jasa Pemerintah Kabupaten Penajam Paser Utara Provinsi Kalimantan Timur). Jurnal Ketahanan Nasional, 21(2), 118. https://doi.org/10.22146/jkn.10155

[11]. Johnson, H. T., \& Kaplan, R. S. (1987). The Rise and Fall of Management Accounting. IEEE Engineering Management Review, 15(3), 36-44. https://doi.org/10.1109/EMR.1987.4306297

[12]. Khan, K. S., Kunz, R., Kleijnen, J., \& Antes, G. (2003). Five steps to conducting a systematic review. Journal of the Royal Society of Medicine, 96(3), 118-121. https://doi.org/10.1258/jrsm.96.3.118

[13]. Kurniawan, M. R., \& Pujiyono, P. (2018). Modus Operandi Korupsi Pengadaan Barang Dan Jasa Pemerintah Oleh Pns. Law Reform, 14(1), 115. https://doi.org/10.14710/lr.v14i1.20241

[14]. Perona, M., Saccani, N., \& Bacchetti, A. (2017). Research vs. Practice on Manufacturing Firms' Servitization Strategies: A Gap Analysis and Research Agenda. Systems, 5(1), 19. https://doi.org/10.3390/systems5010019

[15]. Prabhakar, V. J., \& Sandborn, P. (2012). A part total cost of ownership model for long life cycle electronic systems. International Journal of Computer Integrated Manufacturing, 25(4-5), 384-397. https://doi.org/10.1080/0951192X.2010.531293

[16]. Putra, M. R. A., Atmanto, D., \& Azizah, D. F. (2015). Analisis Sitem Pengadaan Barang/Jasa Pemerintah dalam Meningkatkan Pengendalian Intern . Jurnal Administrasi Bisnis (JAB)|, 2(2).

[17]. Qadri, R. A. (2019). Menakar model pembelian langsung rumah negara di indonesia. Jurnal Pajak dan Keuangan Negara, 1(1).

[18]. Sari, N. (2019). Kilas Balik Bus Transjakarta Zhong Tong yang Bermasalah Era Ahok Halaman all Kompas.com. Diambil 11 Januari 2020, dari Kompas website: https://megapolitan.kompas.com/read/2019/10/15/19071041/kilas-balik-bus-transjakarta-zhong-tong- 

yang-bermasalah-era-ahok?page=all

[19]. Sherif, Y. S., \& Kolarik, W. J. (1981). Life cycle costing: Concept and practice. Omega, 9(3), $287-296$. https://doi.org/10.1016/0305-0483(81)90035-9

[20]. Spitzley, D. V., Grande, D. E., Keoleian, G. A., \& Kim, H. C. (2005). Life cycle optimization of ownership costs and emissions reduction in US vehicle retirement decisions. Transportation Research Part D: Transport and Environment, 10(2), 161-175. https://doi.org/10.1016/j.trd.2004.12.003

[21]. Tranfield, D., Denyer, D., \& Smart, P. (2003). Towards a Methodology for Developing EvidenceInformed Management Knowledge by Means of Systematic Review. British Journal of Management, 14(3), 207-222. https://doi.org/10.1111/1467-8551.00375

[22]. Walterbusch, M., Martens, B., \& Teuteberg, F. (2013). Evaluating cloud computing services from a total cost of ownership perspective. Management Research Review, 36(6), 613-638. https://doi.org/10.1108/01409171311325769

[23]. Wijaya, L. D. (2019). Bus Transjakarta Zhong Tong Muncul Lagi, Tender yang Tertunda. 